\title{
PENGARUH PENAMBAHAN SUATU ELEMEN REAKTIF PADA PERTUMBUHAN KERAK ALUMINA DALAM MATERIAL PADUAN SUHU TINGGI
}

\author{
Sudjatmoko \\ Pusat Teknologi Akselerator dan Proses Bahan - BATAN \\ Jl. Babarsari Kotak Pos 6101 ykbb, Yogyakarta 55281 \\ Diterima 13 Mei 2009; diterima dalam bentuk perbaikan 25 Juni 2009; disetujui 29 Juni 2009
}

\begin{abstract}
ABSTRAK
PENGARUH PENAMBAHAN SUATU EEMEN REAKTIF PADA PERTUMBUHAN KERAK ALUMNA DALAM MATERIAL PADUAN SUHU TINGG. Material paduan suhu tinggi FeAl dan FeCrAl memperlihatkan tahan terhadap oksidasi pada suhu tinggi akibat terbentuknya kerak alumina pada permukaannya. Penambahan sedikit elemen reaktif pada paduan suhu tinggi tersebut telah memperlihatkan perbaikan yang cukup besar dalam sifat oksidasi suhu tinggi. Dalam makalah ini telah dibahas tentang pengaruh penambahan elemen reaktif yttrium terhadap pertumbuhan kerak protektif alumina pada permukaan paduan suhu tinggi FeAl dan FeCrAl. Elemen reaktif yttrium ditambahkan pada permukaan cuplikan FeAl menggunakan teknik implantasi ion dengan dosis ion bervariasi pada orde $10^{15} \mathrm{ion} / \mathrm{cm}^{2}$ dan energi ion $100 \mathrm{keV}$, dan pada cuplikan FeCrAl dengan dosis $10^{17}$ ion/ $\mathrm{cm}^{2}$ dan energi ion $85 \mathrm{keV}$. Uji oksidasi untuk cuplikan FeAl dilakukan dalam media oksigen kering pada suhu $850^{\circ} \mathrm{C}$ dengan beberapa kali siklus termal, dan untuk cuplikan FeCrAl pada suhu $950^{\circ} \mathrm{C}$ dan $1.100^{\circ} \mathrm{C}$, dan karakterisasi komposisi unsur dilakukan menggunakan teknik SEM-EDAX. Selain itu juga dibahas pengaruh penambahan elemen reaktif hafnium dan cerium pada material suhu tinggi. Berdasarkan kajian ini diperoleh bahwa penambahan elemen reaktif pada permukaan material paduan suhu tinggi FeAl dan FeCrAl mempengaruhi pertumbuhan kerak alumina dan meningkatkan ketahanannya terhadap oksidasi suhu tinggi rata-rata sekitar 160\%.
\end{abstract}

Kata kunci : elemen reaktif, material paduan suhu tinggi, kerak alumina, implantasi ion

\begin{abstract}
EFFECT OF THE REACTIVE EEMENT ADDITION ON THE ALUMNA SCALE GROWTH IN HIGH TEMPERATURE MATERIAL ALOYS. The FeAl and FeCrAl high temperature material alloys exhibit the oxidation resistance at high temperatures due to the protective alumina scale formed on their surfaces. Small additions of reactive elements on these high temperature alloys have shown the considerable improvements in high temperature oxidation behaviour. In this paper, the effect of yttrium reactive element additions to alumina protective scale growth on the surface of FeAl and FeCrAl high temperature alloys has been discussed. The yttrium reactive element was added on surface of FeAl samples by using ion implantation techniques with variation of ion dose on the order of $10^{15}$ ion $/ \mathrm{cm}^{2}$ and the ion energy of $100 \mathrm{keV}$, and on the surface of FeCrAl samples with ion dose of $10^{17} \mathrm{ion} / \mathrm{cm}^{2}$ and the ion energy of $85 \mathrm{keV}$. Oxidation test of the FeAl samples was done in dry oxygen media on the temperature of $850^{\circ} \mathrm{C}$ with many times of thermal cycling, while the FeCrAl samples was oxidized on the temperature of $950^{\circ} \mathrm{C}$ and $1,100{ }^{\circ} \mathrm{C}$, and the characterization of elemental composition of the samples were done by using SEM-EDAX techniques. It is also discussed the influence of small additions of hafnium and cerium reactive elements on the high temperature alloys. Based on this study was obtained that the implantation of reactive elements on the surface of the FeAl and FeCrAl high temperature material alloys influence the growth of alumina scale and to increase its high temperature oxidation average around $160 \%$.
\end{abstract}

Keywords : reactive elements, high temperature material alloys, alumina scale, ion implantation

\section{PENDAHULUAN}

Denelitian dan pengembangan material untuk sistem energi maju (advanced energy systems) termasuk reaktor suhu tinggi dan fusi nuklir telah berkembang pesat pada tahun-tahun terakhir ini. Tujuan dari litbang ini adalah mengembangkan material energi yang dapat digunakan dalam sistem energi maju dengan penekanan pada sistem konversi energi maju. Pada saat ini penekanan litbang tersebut adalah kajian material untuk reaktor suhu tinggi dan fusi nuklir dan juga untuk aplikasi ruang angkasa dan lainnya, dimana sangat diperlukan material yang tahan 
terhadap lingkungan ekstrim seperti suhu tinggi, fluks panas yang tinggi, iradiasi partikel energi tinggi dan berbagai tekanan yang sangat kompleks.

Pada saat ini terdapat beberapa metoda untuk meningkatkan ketahanan material terhadap lingkungan suhu sangat tinggi dari $800{ }^{\circ} \mathrm{C}$ hingga $1.300{ }^{\circ} \mathrm{C}$, satu diantaranya adalah menambahkan sejumlah kecil elemen-elemen reaktif (yttrium, cerium, hafnium atau oksidanya) pada permukaan material seperti paduan FeAl dan FeCrAl (1,2,3,4). Penambahan elemen-elemen reaktif tersebut dalam jumlah kecil dapat mengubah mekanisme pertumbuhan oksida protektif dan akan mengakibatkan terjadinya perbaikan sifat ketahanan terhadap oksidasi suhu tinggi (5). Efek elemen reaktif dalam paduan yang membentuk suatu kerak protektif khromia (chromia protective scale) dicirikan dengan terjadinya perbaikan dalam pelekatan kerak (scale adherence) dan pengurangan yang cukup signifikan dalam laju pengelupasan secara parabolik; sedangkan dalam paduan pembentuk kerak alumina (alumina scale), efek yang signifikan adalah perbaikan dalam pelekatan kerak selama oksidasi isotermal dan siklik.

Paduan besi-khromium-aluminium dengan komposisi sekitar 20\% khromium dan 5\% aluminium digunakan secara luas untuk elemen pemanas karena ketahanan oksidasinya sangat tinggi hingga suhu $1.300^{\circ} \mathrm{C}$, dan paduan tersebut juga digunakan sebagai suatu substrat metal untuk konverter katalis kendaraan bermotor (6). Paduan besi-khromium-aluminium tersebut memperlihatkan ketahanan oksidasi yang sangat menyolok pada suhu tinggi, hal ini disebabkan oleh lapisan kerak alumina yang terbentuk pada permukaan paduan ${ }^{(6,7)}$. Alumina, khususnya $\alpha-\mathrm{Al}_{2} \mathrm{O}_{3}$, yang terbentuk pada suhu $1.000{ }^{\circ} \mathrm{C}$ atau lebih mempunyai ketidak-beraturan kisi sangat rendah yang mengakibatkan nilai koefisien difusi dan laju oksidasinya rendah. Berdasarkan pada beberapa teori yang ada, perubahan dalam mekanisme pertumbuhan kerak dapat dijelaskan sebagai berikut. Dalam paduan suhu tinggi FeAl dan FeCrAl tanpa penambahan elemen reaktif, kerak $\mathrm{Al}_{2} \mathrm{O}_{3}$ tumbuh karena terjadinya difusi oksigen ke arah dalam dan difusi aluminium ke arah luar paduan melewati batas-batas butir, sehingga sangat mudah terjadi pengelupasan kerak dari permukaan paduan. Sebaliknya dalam paduan suhu tinggi FeAl atau FeCrAl yang mengandung elemen reaktif, difusi aluminium ke arah luar ditekan dan pertumbuhan kerak $\mathrm{Al}_{2} \mathrm{O}_{3}$ terjadi terutama oleh difusi oksigen ke dalam paduan sepanjang batas-batas butir, sehingga adesinya lebih baik dan laju pertumbuhannya berkurang ${ }^{(7,8)}$. Penambahan elemen reaktif tersebut bertujuan untuk menghasilkan struktur-mikro dengan butiran-butiran yang halus dan untuk memperbaiki sifat oksidasi, sedangkan sifat mekanik yang menguntungkan masih dapat dipertahankan (9).

Penambahan sejumlah kecil elemen-elemen reaktif seperti yttrium, cerium, hafnium atau oksidanya pada paduan FeAl dan FeCrAl dapat dilakukan dengan beberapa teknik, yaitu penambahan elemen reaktif dalam bentuk larutan, dispersi oksida (oxide dispersion), pelapisan permukaan (surface coating), pemaduan (alloying) atau implantasi ion $(1,10,11)$. Teknik yang terakhir yaitu implantasi ion memberikan beberapa keunggulan antara lain yaitu penambahan satu atau lebih elemen pada lapisan dekat permukaan suatu material paduan dapat dikontrol dengan akurat, baik konsentrasi dan kedalaman penetrasi elemen yang diimplantasikan, dan dapat diulangi dengan hasil yang sama. Dalam makalah ini dibahas penambahan suatu elemen reaktif, yaitu yttrium, cerium dan hafnium, pada logam paduan FeAl dan FeCr Al dengan teknik implantasi ion, dan pengaruhnya pada pertumbuhan kerak alumina dan peningkatan paduan tersebut terhadap ketahanan oksidasi suhu tinggi. Diharapkan hasil kajian ini memberikan kontribusi dalam bidang industri material suhu tinggi dan material reaktor suhu tinggi, khususnya dalam pengembangan material yang tahan terhadap lingkungan ekstrim seperti suhu tinggi, fluks panas yang tinggi dan berbagai tekanan dalam kondisi lingkungan yang sangat kompleks.

\section{METODOLOGI}

Dalam makalah ini dilakukan kajian pada material paduan suhu tinggi FeAl dan material paduan berbasis FeCrAl, yaitu INCOLOY alloy MA956 yang struktur-mikronya terdiri dari dispersi partikel oksida yttrium yang sangat halus dalam matriks FeCrAl, sedangkan elemen reaktif yang ditambahkan pada paduan tersebut adalah serbuk yttrium dengan kemurnian 99,9\%. Fasilitas yang digunakan antara lain terdiri dari alat pemotong cuplikan, penghalus cuplikan, pembersih cuplikan ultrasonik (ultrasonic cleaner), akselerator implantasi ion $200 \mathrm{keV} / 2 \mathrm{~mA}$ buatan PTAPB-BATAN, tabung furnace tipe RTI/AGG : $220 \mathrm{~V} / 45$ A dengan suhu maksimum $1.100{ }^{\circ} \mathrm{C}$, neraca analitis GR series : beban minimum 0,1 mg dan beban maksimum $210 \mathrm{~g}$, dan peralatan SEM (Scanning Electron Microscope) dan EDAX (Energy Dispersive Analysis X-ray).

Potongan cuplikan dalam bentuk keping dihaluskan permukaannya menggunakan kertas ampelas, selanjutnya dipoles menggunakan pasta intan dan digosok dengan kain beludru sampai dihasilkan permukaan yang 
halus dan mengkilap. Untuk menghilangkan kotoran pada permukaan cuplikan dilakukan pencucian menggunakan alkohol dan kemudian dimasukkan ke dalam pembersih ultrasonik. Pengeringan cuplikan dilakukan dalam oven, kemudian disimpan dalam desikator agar cuplikan tidak terkontaminasi oleh udara.

Dalam kajian ini untuk menambahkan elemen reaktif yttrium ke dalam permukaan cuplikan dilakukan dengan menggunakan teknik implantasi ion, dan fasilitas akselerator implantasi ion yang digunakan adalah buatan PTAPB-BATAN Yogyakarta. Ada dua besaran penting dalam proses implantasi ion, yaitu kedalaman penetrasi ion pada permukaan cuplikan dan distribusi konsentrasi ion yang diimplantasikan. Parameter kedalaman penetrasi ion adalah jenis ion dan energi ion yang diimplantasikan serta jenis cuplikan atau material; sedangkan parameter yang mempengaruhi distribusi konsentrasi ion adalah arus berkas ion dan lamanya proses implantasi ion berlangsung. Dalam kajian ini dosis ion bervariasi dengan mengubah waktu atau lamanya proses implantasi, sedangkan arus berkas ion dibuat tetap $10 \mu \mathrm{A}$ karena pada arus berkas ion ini diperoleh kondisi yang paling stabil. Pada cuplikan FeAl dilakukan implantasi ion yttrium dengan variasi dosis orde 1015 ion/ $/ \mathrm{cm}^{2}$ dan energi ion $100 \mathrm{keV}$; sedangkan pada cuplikan berbasis FeCrAl diimplantasi dengan dosis ion yttrium $10^{17} \mathrm{ion} / \mathrm{cm}^{2}$ dan energi ion $85 \mathrm{keV}$.

Uji oksidasi dilakukan untuk cuplikan sebelum dan sesudah proses implantasi ion, dan dilakukan dalam kondisi siklus termal dengan menggunakan tabung furnace. Sebagai tempat cuplikan digunakan tabung kaca jenis kuarsa yang tahan panas hingga suhu sekitar $1.100^{\circ} \mathrm{C}$. Uji oksidasi dilakukan dalam media oksigen kering dengan mengalirkan gas oksigen tekanan 1 bar selama beberapa kali siklus termal. Pada cuplikan FeAl, setiap siklus termal adalah 7 jam pemanasan pada suhu $850^{\circ} \mathrm{C}$ dan pendinginan selama 17 jam pada suhu kamar; sedangkan untuk cuplikan berbasis FeCrAl dioksidasi pada suhu $950^{\circ} \mathrm{C}$ dan $1.100{ }^{\circ} \mathrm{C}$ selama 100 jam. Penimbangan berat cuplikan dilakukan setiap kali siklus termal dan dicatat perubahan berat cuplikan $(\Delta \mathrm{m})$, kemudian dibuat grafik antara perubahan berat cuplikan dengan waktu oksidasi.

Untuk mengetahui apakah elemen reaktif telah terimplantasi pada permukaan cuplikan dan untuk mengetahui kerak atau lapisan oksida protektif yang terbentuk pada permukaan cuplikan digunakan teknik SEM-EDAX. Peralatan SEM ini menggunakan hamburan balik dan pantulan sekunder dari berkas elektron setelah berkas elektron berinteraksi dengan materi atau cuplikan. Hasil interaksi tersebut berupa pantulan elektron-elektron sekunder, elektron-elektron yang terhambur dan radiasi sinar-X karakteristik akan memberikan informasi mengenai keadaan cuplikan seperti bentuk permukaan (topografi) dan komposisi kimia yang terkandung dalam cuplikan. Radiasi sinar-X karakteristik yang dipancarkan oleh cuplikan dapat memberikan informasi secara kualitatif dan kuantitatif tentang komposisi kimia dari cuplikan.

\section{HASIL DAN PEMBAHASAN}

Lapisan kerak atau oksida protektif alumina $\mathrm{Al}_{2} \mathrm{O}_{3}$ yang tumbuh secara termal pada permukaan material paduan suhu tinggi seperti FeAl dan FeCrAl memainkan peranan penting dalam suatu lingkungan yang ekstrim dengan kisaran suhu tinggi 800 hingga $1.300^{\circ} \mathrm{C}$. Penambahan elemen reaktif yttrium pada paduan suhu tinggi tersebut meningkatkan ketahanan oksidasi suhu tinggi dengan mencegah terjadinya pengelupasan kerak alumina. Dalam penelitian ini digunakan material paduan suhu tinggi berbasis FeCrAl, yaitu INCOLOY alloy MA956 yang merupakan suatu paduan oxide dispersion strengthened (ODS) yang dihasilkan dengan proses pemaduan mekanik. Struktur-mikronya terdiri dari dispersi partikel oksida yttrium sangat halus dalam matriks FeCrAl, dan komposisi nominal dari paduan tersebut adalah (dalam \% berat) : Fe-20Cr-4,5Al-0,5Ti-0,5 $\mathrm{Y}_{2} \mathrm{O}_{3}$. Cuplikan MA956 diimplantasi dengan ion yttrium pada energi $85 \mathrm{keV}$ dan dosis $1 \times 10^{17} \mathrm{ion} / \mathrm{cm}^{2}$, kemudian cuplikan non implantasi dan cuplikan yang diimplantasi diuji oksidasi di atmosfir pada suhu $950^{\circ} \mathrm{C}$ selama 100 jam. Gambar 1(a) dan 1(b) masing-masing menyajikan tampang-lintang mikrograf-SEM dari cuplikan yang diimplantasi dengan ion yttrium dan cuplikan non implantasi setelah proses oksidasi(12). Tampang-lintang mikrograf-SEM dan spektrum EDAX diperoleh dengan menggunakan peralatan SEM-EDAX yang ada di GFE RWTH-Aachen, Jerman dalam kerangka kerjasama penelitian "Development of Materials for Metal Supported Automotive Catalysts" antara pemerintah Indonesia dan Jerman.

Berdasarkan Gambar 1(a) terlihat bahwa lapisan kerak atau oksida protektif alumina tumbuh relatif merata dan melekat kuat pada material induknya, hal ini terjadi karena adanya penambahan elemen reaktif yttrium pada permukaan cuplikan dan penambahan ini ditunjukkan pada Gambar 1(c). Sedangkan pada Gambar 1(b) ditampilkan tampang-lintang mikrografi-SEM dari cuplikan non implantasi dan terlihat terjadinya keretakan dan pengelupasan kerak alumina dari permukaan material induknya. Hal ini terjadi kemungkinan karena pada cuplikan 
berbasis FeCrAl atau MA956 tanpa penambahan elemen reaktif, kerak $\mathrm{Al}_{2} \mathrm{O}_{3}$ tumbuh karena terjadinya difusi oksigen ke arah dalam dan difusi aluminium ke arah luar paduan melewati batas-batas butir, sehingga daya lekatnya kurang dan sangat mudah terjadi pengelupasan kerak dari permukaan material induknya.

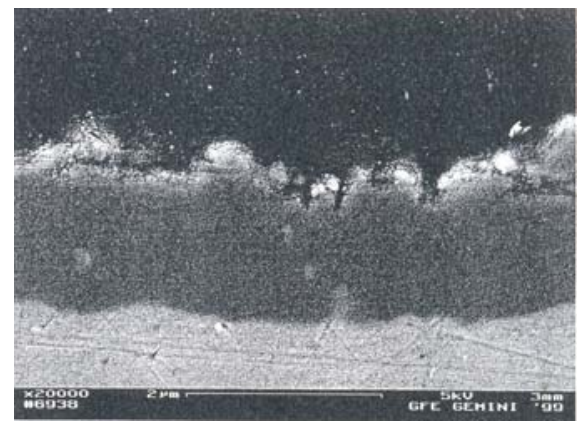

(a)

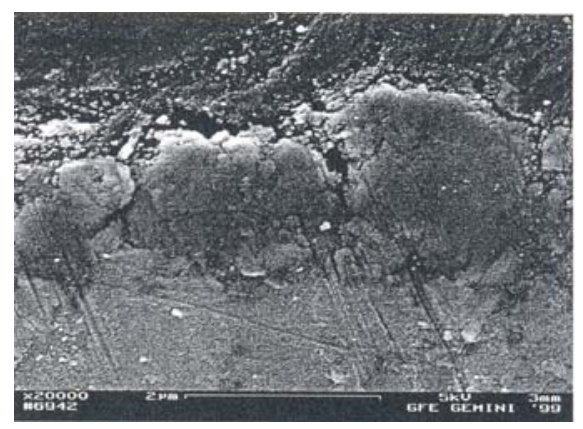

(b)

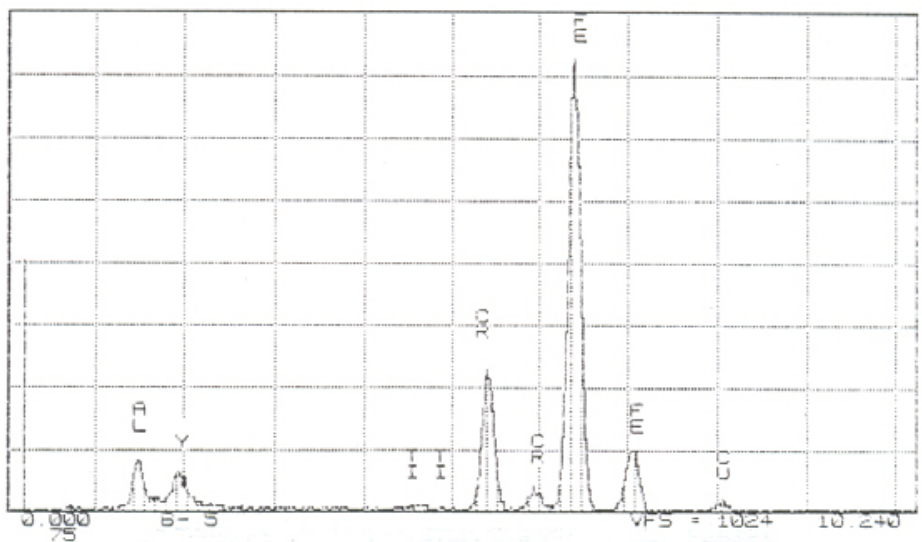

(c)

Gambar 1. Tampang-lintang mikrograf-SEM, (a) cuplikan MA956 yang diimplantasi dengan ion yttrium, (b) cuplikan MA956 yang tidak diimplantasi, setelah proses oksidasi di atmosfir pada suhu $950^{\circ} \mathrm{C}$ selama 100 jam, dan (c) spektrum EDAX permukaan cuplikan.

Pada cuplikan MA956 tersebut di atas, selain dilakukan proses oksidasi pada suhu $950{ }^{\circ} \mathrm{C}$ juga dilakukan oksidasi di atmosfir pada suhu $1.100{ }^{\circ} \mathrm{C}$ dengan proses oksidasi berlangsung selama 100 jam. Gambar 2(a) dan 2(b) masing-masing menyajikan tampang-lintang mikrograf-SEM dari cuplikan setelah proses oksidasi, dan spektrum EDAX pada lapisan oksida yang terbentuk (13). Berdasarkan Gambar 2(a) dapat dilihat terjadinya pertumbuhan lapisan kerak atau oksida protektif alumina pada permukaan cuplikan setelah dilakukan proses oksidasi pada suhu $1.100{ }^{\circ} \mathrm{C}$ selama 100 jam. Kerak alumina tersebut tumbuh cukup merata pada permukaan cuplikan dan tidak terjadi keretakan dan pengelupasan dari material induknya, hal ini terjadi karena adanya penambahan elemen reaktif yttrium dengan dosis $1 \times 10^{17} \mathrm{ion} / \mathrm{cm}^{2}$. 


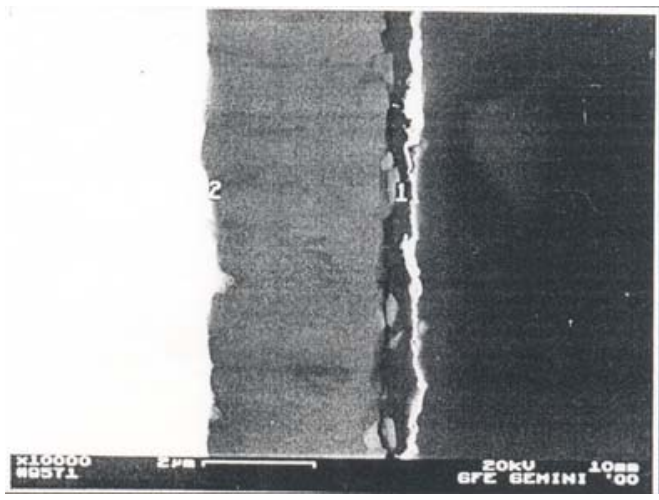

(a)

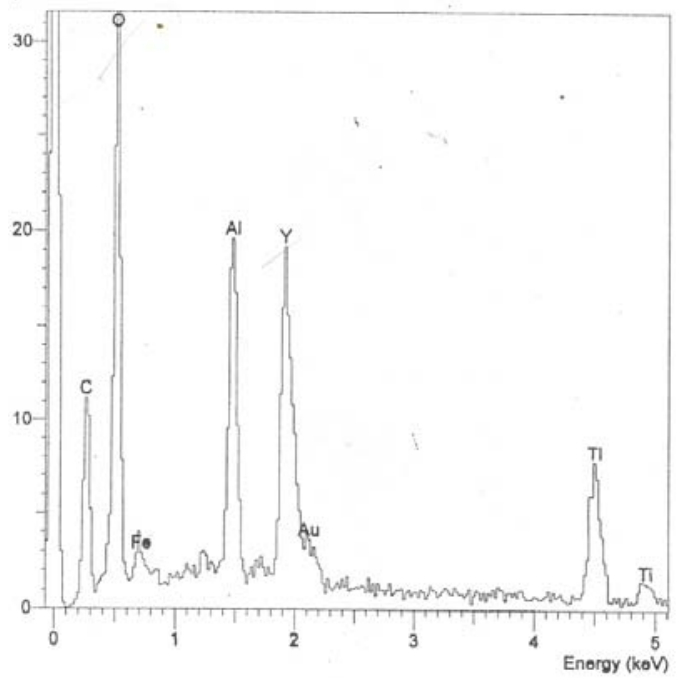

(b)

Gambar 2. Tampang-lintang mikrografi-SEM, (a) cuplikan MA956 yang diimplantasi dengan ion yttrium setelah oksidasi pada $1.100{ }^{\circ} \mathrm{C}$ selama $100 \mathrm{jam}$, dan (b) spektrum EDAX pada lapisan oksida.

Pada Gambar 2(b) ditampilkan spektrum EDAX dari lapisan oksida yang terbentuk pada permukaan cuplikan MA956 setelah proses oksidasi pada suhu $1.100^{\circ} \mathrm{C}$ selama 100 jam. Berdasarkan Gambar 2(b) tersebut dapat diketahui bahwa pada permukaan cuplikan terdapat elemen reaktif yttrium hasil dari implantasi ion yttrium. Oleh karena itu, selama proses oksidasi di atmosfir pada suhu $1.100{ }^{\circ} \mathrm{C}$ selama $100 \mathrm{jam}$, selain terbentuk lapisan kerak alumina juga akan tumbuh oksida yttrium karena terjadinya difusi oksigen ke dalam material paduan. Pertumbuhan oksida yttrium inilah yang memberikan efek sangat signifikan pada peningkatan ketahanan suatu material terhadap oksidasi suhu tinggi. Seperti telah dijelaskan di atas, penambahan elemen reaktif yttrium menghambat terjadinya difusi aluminium ke arah luar dan pertumbuhan kerak alumina terjadi terutama oleh efek difusi oksigen ke dalam paduan sepanjang batas-batas butir, sehingga daya lekat lapisan kerak atau oksida protektif alumina terhadap material induknya menjadi lebih baik dan laju pertumbuhannya menjadi lebih lambat, dan hal ini memperkecil terjadinya keretakan dan pengelupasan kerak alumina dari material induknya.

Pada makalah ini juga dibahas penambahan elemen reaktif hafnium dan yttrium pada material berbasis FeAl, yaitu iron-aluminide Fe-28Al-2Cr, dan pengaruhnya pada suhu tinggi. Hasil eksperimen yang diperoleh dapat dilihat pada Gambar 3(a) yang menampilkan hasil uji siklus termal dari iron-aluminide selama siklus termal 500 jam pada $1.000{ }^{\circ} \mathrm{C}$ dalam lingkungan udara, dan Gambar 3(b) adalah mikrograf FEG-SEM (field emission gun-scanning electron microscopy) dari oksida yang terspalasi pada FAS (Fe-28Al-2CR)+0,05\%Hf setelah siklus 5.000 jam pada $1.000{ }^{\circ} \mathrm{C}$ (14). Berdasarkan pada Gambar 3(a) dapat diketahui bahwa penambahan elemen reaktif $\mathrm{Hf}$ pada paduan berbasis FAS (Fe-28Al-2Cr) memberikan efek yang bermanfaat pada sifat oksidasi apabila ditambahkan hingga 
tingkat sekitar 0,1 at.\%, akan tetapi sifat ketahanan oksidasi suhu tinggi yang lebih baik diperoleh pada penambahan $0,05 \% \mathrm{Hf}$. Hal ini dapat dilihat dari laju penambahan massa cuplikan FAS+0,05\%Hf yang lebih lambat dan kecil jika dibandingkan dengan laju penambahan massa cuplikan FAS+0,1\%Hf. Berdasarkan Gambar 3(a) juga dapat dilihat bahwa penambahan elemen reaktif yttrium pada PMFAS (yttria-dispersed Fe-28Al-2Cr) menghasilkan oksida $\mathrm{Y}_{2} \mathrm{O}_{3}$ yang memberikan ketahanan oksidasi suhu tinggi lebih baik, hal ini ditunjukkan dengan penambahan massa cuplikan yang lebih lambat dibandingkan dengan FAS $+0,05 \% \mathrm{Hf}$. Paduan mengalami spalasi pada suhu $1.100{ }^{\circ} \mathrm{C}$ kecuali FeCrAlY (PMFAS), dimana penambahan massa cuplikan dan massa total adalah sama. Sedangkan Gambar 3(b) memperlihatkan mikrograf FEG-SEM terjadinya spalasi oksida yang terbentuk pada FAS $+0,05 \% \mathrm{Hf}$ setelah siklus termal 5.000 jam pada $1.000{ }^{\circ} \mathrm{C}$. Penambahan $0,05 \% \mathrm{Hf}$ tidak mengeliminasi spalasi oksida alumina yang terbentuk pada permukaan cuplikan, akan tetapi hanya mengurangi laju pertumbuhan kerak oksida.
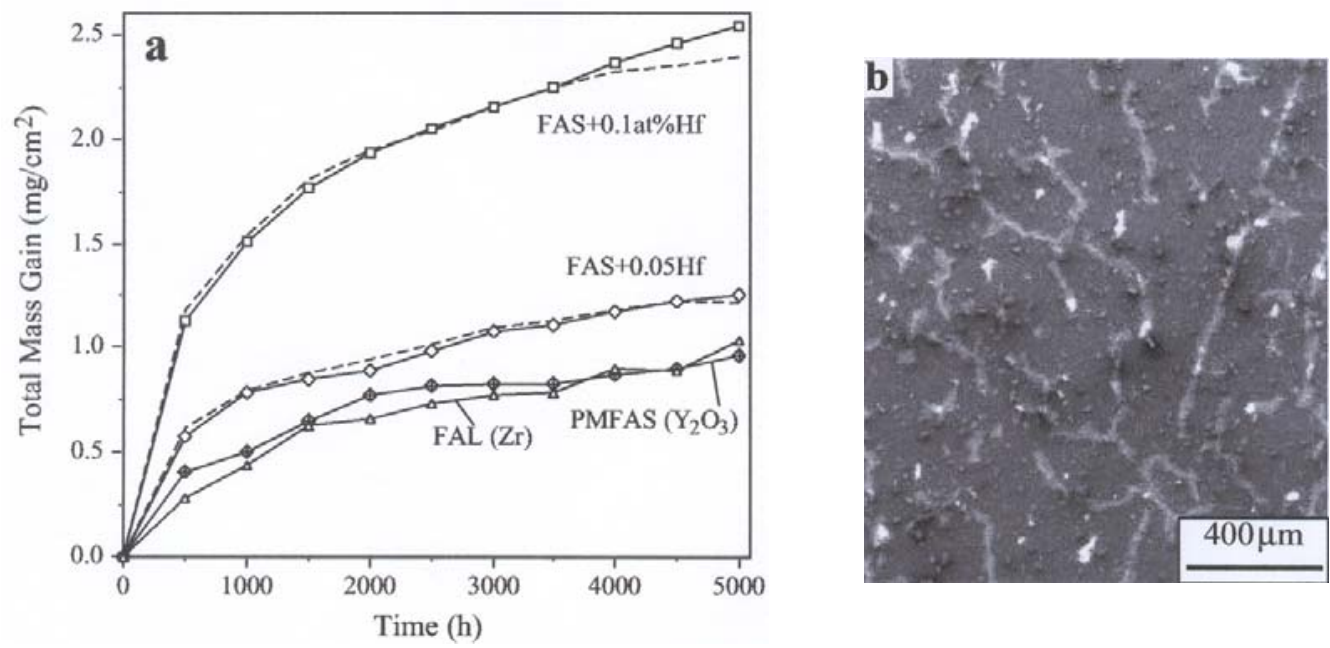

Gambar 3. (a) Garis putus-putus memperlihatkan penambahan massa cuplikan dan garis penuh memperlihatkan penambahan massa total (cuplikan + oksida terspalasi) untuk beberapa iron-aluminide (Fe-28Al-2Cr) selama siklus termal 500 jam pada $1000{ }^{\circ} \mathrm{C}$ dalam lingkungan udara; (b) mikrograf FEG-SEM dari oksida yang terspalasi pada FAS+0,05Hf setelah siklus 5000 jam pada $1000^{\circ} \mathrm{C}$.

Pada kajian ini juga dibahas hasil penambahan elemen reaktif yttrium dan cerium pada material FeAl. Pada Gambar 4(a) ditampilkan hasil karakterisasi laju oksidasi material FeAl yang ditambah dengan elemen reaktif yttrium dan cerium pada dosis optimum masing-masing $D_{o p}(Y)=2,98 \times 10^{15}$ ion $/ \mathrm{cm}^{2}$ dan $D_{o p}(C e)=5,96 \times 10^{15}$ ion/ $\mathrm{cm}^{2}$. Berdasarkan hasil uji siklus termal pada Gambar 4(a) terlihat bahwa penambahan elemen reaktif yttrium dan cerium dapat meningkatkan ketahanan cuplikan FeAl terhadap oksidasi suhu tinggi, jika dibandingkan dengan cuplikan tanpa diimplantasi (15). Untuk cuplikan FeAl yang diimplantasi dengan ion yttrium, proses oksidasi pada siklus termal $0-2$, yaitu antara 0 hingga 14 jam terjadi penambahan berat sangat signifikan sebagai akibat proses oksidasi yang terjadi karena adanya penangkapan atom-atom oksigen oleh cuplikan membentuk oksida protektif. Pada siklus termal 2 -3 dan berikutnya pada siklus termal 3 - 4 relatif stabil tidak terjadi penambahan berat cuplikan, akan tetapi terjadi pembentukan lapisan oksida pada siklus termal $4-5$ dan kemudian terjadi pengelupasan lapisan oksida pada siklus termal $5-6$ yang ditandai dengan pengurangan berat cuplikan. Berdasarkan uji siklus termal tersebut dapat diketahui bahwa dosis ion yttrium optimum diperoleh pada dosis $2,98 \times 10^{15} \mathrm{ion} / \mathrm{cm}^{2}$. Untuk cuplikan FeAl yang diimplantasi dengan elemen reaktif cerium, pada siklus termal $0-1$, yaitu antara 0 hingga 7 jam terjadi penambahan berat sangat signifikan sebagai akibat proses oksidasi yang terjadi karena adanya penangkapan atom-atom oksigen oleh cuplikan membentuk oksida protektif. Pada siklus termal $1-2$ terjadi sedikit pengurangan berat karena terjadi pengelupasan lapisan oksida; selanjutnya pada siklus 2 - 3 terjadi sedikit penambahan berat karena terjadi lagi pertumbuhan lapisan oksida proteksi. Hal ini terjadi secara berulang hingga siklus termal ke 6 , 
dan secara keseluruhan dengan implantasi ion cerium pada dosis 5,96 $\times 10^{15}$ ion $/ \mathrm{cm}^{2}$ terjadi peningkatan ketahanan terhadap oksidasi suhu tinggi. Sedangkan Gambar 4(b) memperlihatkan hasil karakterisasi menggunakan SEM memberikan morfologi permukaan cuplikan. Berdasarkan hasil karakterisasi dengan SEM tersebut dapat diketahui bahwa morfologi permukaan cuplikan FeAl terlihat relatif teratur dan menghasilkan struktur-mikro dengan butiran-butiran yang halus dan tidak terlihat terjadinya spalasi atau pengelupasan kerak oksida pada permukaan cuplikan.

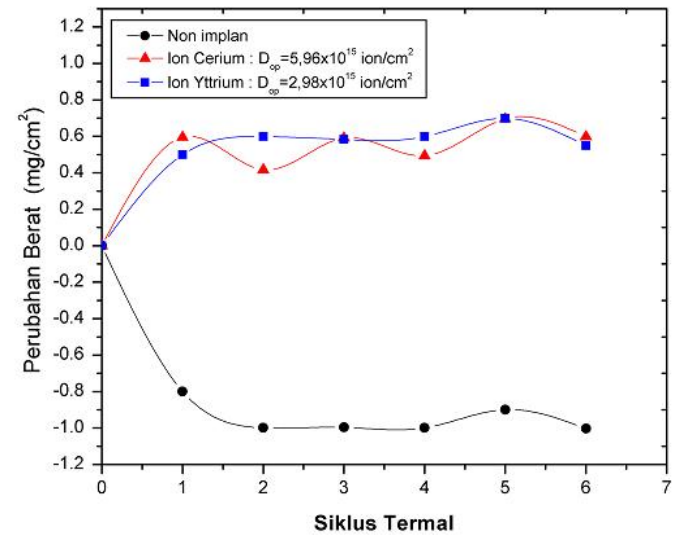

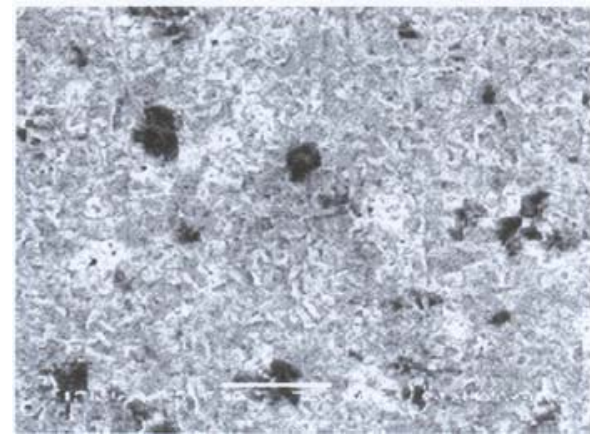

(b)

(a)

Gambar 4. (a) Laju oksidasi cuplikan FeAl yang tidak diimplantasi dan yang diimplantasi ion yttrium dengan dosis optimum $D_{o p}=2,98 \times 10^{15}$ ion $/ \mathrm{cm}^{2}$, dan ion cerium dengan dosis optimum $D_{o p}=5,96 \times$ $10^{15} \mathrm{ion} / \mathrm{cm}^{2}$; (b) Morfologi permukaan material FeAl yang diimplantasi ion yttrium dosis 2,98 × $10^{15} \mathrm{ion} / \mathrm{cm}^{2}$ setelah mengalami enam kali siklus termal.

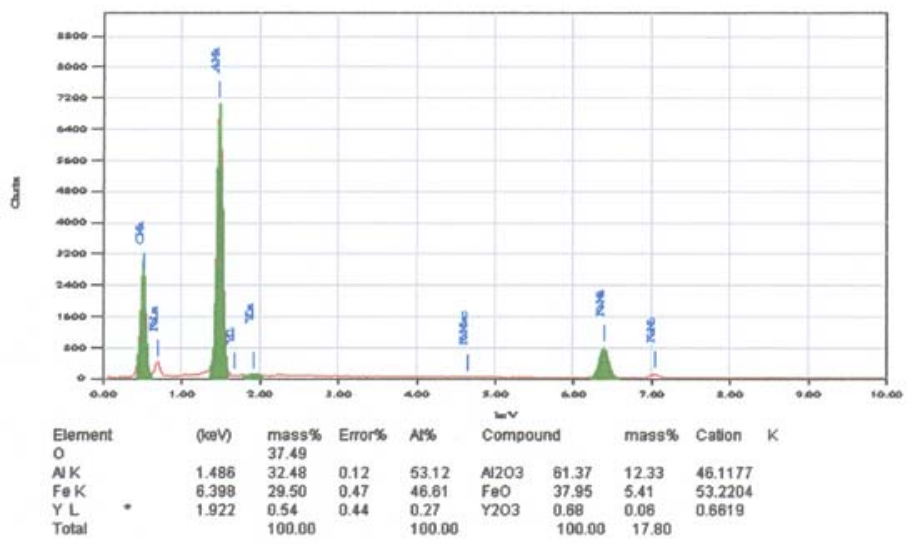

Gambar 5. Komposisi unsur cuplikan FeAl yang diimplantasi ion yttrium dengan dosis 2,98 $\times 10^{15} \mathrm{ion} / \mathrm{cm}^{2}$ setelah mengalami enam kali siklus termal.

Selain dilakukan uji siklus termal, cuplikan FeAl yang diimplantasi dengan elemen reaktif yttrium dan cerium juga diamati morfologi permukaan dan komposisi unsurnya. Gambar 5 memperlihatkan hasil karakterisasi komposisi unsur dengan SEM-EDAX dari material FeAl diimplantasi ion yttrium pada dosis 2,98 $\times 10^{15} \mathrm{ion} / \mathrm{cm}^{2}$ setelah mengalami enam kali siklus termal (15).

Hasil karakterisasi SEM-EDAX dari cuplikan FeAl tersebut memperlihatkan adanya unsur-unsur O, Al, Fe dan $\mathrm{Y}$ serta lapisan oksida $\mathrm{Al}_{2} \mathrm{O}_{3}, \mathrm{FeO}$ dan $\mathrm{Y}_{2} \mathrm{O}_{3}$. Lapisan alumina atau oksida $\mathrm{Al}_{2} \mathrm{O}_{3}$ yang terbentuk adalah sebesar $61,37 \%$ massa, sedangkan lapisan oksida yttrium yang terbentuk mencapai $0,68 \%$ massa. Pertumbuhan lapisan oksida yttrium tersebut berfungsi menekan terjadinya difusi aluminium ke arah luar, dan pertumbuhan oksida $\mathrm{Al}_{2} \mathrm{O}_{3}$ terutama disebabkan oleh difusi oksigen ke dalam paduan sepanjang batas-batas butir, menyebabkan daya 
lekatnya lebih baik dan laju pertumbuhannya berkurang, sehingga material paduan tersebut tahan terhadap oksidasi suhu tinggi.

\section{KESIMPULAN}

Berdasarkan hasil dan pembahasan tersebut di atas dapat diambil beberapa kesimpulan sebagai berikut.

1. Penambahan sedikit elemen-elemen reaktif yttrium $0,27 \%$ atom, cerium $0,39 \%$ atom dan hafnium $0,05 \%$ atom pada bahan paduan suhu tinggi berbasis FeCrAl dan FeAl dengan teknik implantasi ion memberikan hasil yang cukup baik pada peningkatan ketahanan terhadap oksidasi suhu tinggi rata-rata sekitar $160 \%$.

2. Berdasarkan hasil uji oksidasi cuplikan non implantasi pada suhu $\geq 850^{\circ} \mathrm{C}$ dapat diketahui bahwa pada permukaan cuplikan tumbuh lapisan kerak atau oksida protektif alumina yang berfungsi melindungi material induk terhadap oksidasi suhu tinggi, akan tetapi terjadi keretakan dan pengelupasan kerak alumina dari material induknya pada saat terjadi proses siklus termal.

3. Pada cuplikan yang dimplantasi dengan ion yttrium setelah proses oksidasi pada suhu $\geq 850{ }^{\circ} \mathrm{C}$ terjadi pertumbuhan lapisan kerak atau oksida protektif almunia dan oksida yttrium pada permukaan cuplikan. Penambahan elemen reaktif yttrium pada permukaan cuplikan memperkecil proses difusi aluminium ke arah luar, sehingga pertumbuhan kerak alumina terutama disebabkan oleh difusi oksigen ke dalam paduan sepanjang batas-batas butir, sehingga daya lekat kerak alumina pada material induknya menjadi lebih baik dan laju pertumbuhannya berkurang. Kejadian ini mengakibatkan terjadinya peningkatan ketahanan oksidasi yang cukup signifikan pada suhu tinggi dan proses siklus termal.

\section{UCAPAN TERIMA KASIH}

Pada kesempatan ini penulis mengucapkan terima kasih kepada Sdr. Sunarto yang telah membantu melakukan eksperimen dan pengambilan data, sehingga penelitian ini dapat diselesaikan. Semoga amal baik Saudara sekalian mendapat balasan dari Allah SWT. Amien.

\section{DAFTAR PUSTAKA}

1. STRAWBRIDGE and P.Y. HOU, The role of reactive elements in oxide scale adhesion, Materials at High Temperatures, 12 (2-3) (1994) 177-181

2. F.H., SCOTT, The Oxidation of Alumina-Forming Alloys, Materials Science Forum, 251-254 (1997) 19-32

3. S. SEAL, et al., Role of surface chemistry on the nature of passive oxide film growth on $\mathrm{Fe}-\mathrm{Cr}$ (low and high) steels at high temperatures, Journal of Vacuum Science and Technology, A 17 (4) (1999) 1109-1115

4. T. AMANO, et al., The morphology of alumina scales formed on Fe-20Cr-4Al-S alloys with reactive element ( $Y$, $\mathrm{Hf)}$ additions at $1273 \mathrm{~K}$, Materials at High Temperature, Vol. 20, Issue 3, (2003)

5. D.L. RAMA, G.J. TATLOCK and U. FALKE, Segregation of reactive elements at oxide grain boundaries in FeCrAIRE alloys, Materials at High Temperature 22(3/4) (2005)

6. J. KLOWER, Factors affecting the oxidation behaviour of thin Fe-Cr-Al foils, Materials and Corrosion 49 (1998) 758-763

7. K. ISHII, et al., Effect of Rare-Earth Elements on High-Temperature Oxidation Resistance of Fe-20Cr-5Al Alloy Foils, Materials Transactions, JIM, 38 (9) (1997) 787-792

8. H.J. GRABKE, M. SIEGERS and V.K. TOLPYGO, Oxidation of Fe-Cr-Al and Fe-Cr-Al-Y Single Crystals, Z. Naturforsch, 50a, (1995) 217-227

9. M.A. MONTEALEGRE, et al., Oxidation behaviour of novel ODS FeA/Cr intermetallic alloys, Intermetallics 13 (2005) 896-906

10. V.A.C. HAANAPPEL and M.F. STROOSNIJDER, Ion implantation technique as research tool for improving oxidation behaviour of TiAl based intermetallic alloys, Surface Engineering, 15 (2) (1999) 119-125

11. G. SCHUMACHER, et al., Improvement of the oxidation resistance of gamma titanium aluminides by microalloying with chlorine using ion implantation, Materials and Corrosion 50, (1999) 162-165

12. SUDJATMOKO, dkk., "Perbaikan Ketahanan Oksidasi Suhu Tinggi Bahan MA956 Dengan Penambahan Elemen Reaktif Yttrium Menggunakan Teknik Implantasi Ion", Prosiding Pertemuan dan Presentasi Ilmiah Teknologi Akselerator dan Aplikasinya, 3 (1), Yogyakarta (2001) 
13. M. DANI, et al., Report : Development of Materials for Metal Supported Automotive Catalysts Project IDN 99/004, GFE RWTH-Aachen, Germany, November (2000)

14. B.A. PINT, et al., Optimizing the Imperfect Oxidation Performance of Iron Aluminides, Oak Ridge National Laboratory, P.O. Box 2008, M.S.6156, Oak Ridge, TN 37831-6156 USA

15. SUDJATMOKO, dkk., "Pengaruh Implantasi Elemen Reaktif Pada Material FeNiCr dan FeAl Untuk Meningkatkan Ketahanan Oksidasi Suhu Tinggi", Prosiding Pertemuan dan Presentasi Ilmiah Teknologi Akselerator dan Aplikasinya, 9, Yogyakarta (2007) 